\title{
Prognostic value of IL-6 and IL- 0 serum levels and immunonutritional assessment in determining postoperative complications after geriatric surgery
} Bianca Cudia1, Carmela Rita Balistreri ${ }^{2}$, Giovanni Guercio ${ }^{1}$,
Francesco Bavetta $^{1}$, Calogero Ricotta

\author{
Address: ${ }^{1}$ Department of Surgery GEN.UR.TO, University of Palermo, Palermo, Italy and ${ }^{2}$ Department of Pathobiology and Biomedical \\ Methodologies, University of Palermo, Palermo, Italy \\ * Corresponding author
}

from XXI Annual Meeting of The Italian Society of Geriatric Surgery

Terni, Italy. 4-6 December 2008

Published: I April 2009

BMC Geriatrics 2009, 9(SuppI I):A92 doi:10.1 186/I47I-23I8-9-SI-A92

This abstract is available from: http://www.biomedcentral.com/I47I-23I8/9/SI/A92

(C) 2009 Cudia et al; licensee BioMed Central Ltd.

\section{Background}

The onset of postoperative septic complications has recently been associated to serum levels of interleukin (IL) IL-6 and IL-10. Patients with complications have higher serum levels than patients without complication after surgery. IL-6 has been recognized as early marker of postoperative septic events. Furthermore IL-6 increases with age, expecially if there are associated diseases. It is a sign of functional deterioration of different organs.

The disregulation in interleukin production, anesthetic drugs, hemorrhage and transfusions may lead to the onset of postoperative complications. The latter are more frequent in oncologic patients.

The aim of our study is to evaluate pre- and postoperative profile of some inflammatory markers (IL-6, IL-10 and Creactive protein CRP) and immunonutritional assessment (through albumin serum levels and lymphocyte count) in a group of elderly patients undergone to major intrabdominal surgery. We related the data obtained to the onset of postoperative complications.

\section{Materials and methods}

We evaluated 55 patients, 25 males and 30 females, aged $\geq 70$ (median 75 , range $70-89$ ). The only preoperative criterium for inclusion was non urgent major abdominal surgery, the exclusion criteria were: urgent abdominal sur- gery, chronic therapy with antinflammatory drugs, therapy with steroid and/or immunosuppressor drugs during 30 days before the admission. For each patient we collected three peripheral venous blood samples, at preoperative time $0(\mathrm{t} 0)$, and then at first $(\mathrm{t} 1)$ and seventh postoperative day. Cytokine evaluation on serum samples was obtained by ELISA method with "sandwich" technique. For each patient we considered the length of postoperative time, any transfusion and any postoperative complication. Among the latter we considered: surgical wound infection; urinary tract infection; respiratory infection/respiratory failure; SIRS and/or sepsis; anastomotic leakage; peritonitis.

\section{Results}

We observed 12 complications, including one death, corresponding to $21.8 \%$ of all evaluated patients (Table 1 ).

All subjects at $\mathrm{t} 1$ showed an elevation of IL- 6 levels, more consistent in the complicated ones $(137.69 \pm 91.13 \mathrm{pg} / \mathrm{ml}$ vs $108.86 \pm 52.62 \mathrm{pg} / \mathrm{ml})$. IL-10 presented the same trend of IL-6, moreover it showed lower basic levels (t0) in complicated patients $(19.02 \pm 16.73 \mathrm{pg} / \mathrm{ml}$ vs $9.31 \pm 11.17)$. The CRP values didn't differ at any time between the two groups. The lymphocyte count showed a higher basic level (t0) in complicated patients, but a deeper decrement at t1 in the same group. Finally, albumin serum levels were the 
Table I:

\begin{tabular}{ll}
\hline Postoperative complications & Number of patients \\
\hline Anastomotic leakage & 2 \\
Abdominal wall necrosis & $\mathrm{I}$ \\
Respiratory failure & 3 \\
Urinary tract infection & $\mathrm{I}$ \\
Surgical wound infection & $\mathrm{I}$ \\
Respiratory infection & $\mathrm{I}$ \\
Sepsis & $\mathrm{I}$ \\
Septic shock, CID & $\mathrm{I}$ \\
\hline
\end{tabular}

same at t0 for all patients and they decreased much more than in the complicated ones.

\section{Conclusion}

In the group of elderly patients observed, as in general population according to published data, IL-6 and IL-10 may be referred as prognostic markers regard to postoperative complication. It would be moreover useful to identify a cut-off value to select the subjects with a higher postoperative risk. About this topic, CRP trend and lymphocyte count have no role because of lack of sensitivity.

Publish with Bio Med Central and every scientist can read your work free of charge

"BioMed Central will be the most significant development for disseminating the results of biomedical research in our lifetime. "

Sir Paul Nurse, Cancer Research UK

Your research papers will be:

- available free of charge to the entire biomedical community

- peer reviewed and published immediately upon acceptance

- cited in PubMed and archived on PubMed Central

- yours - you keep the copyright 